\title{
IMPLEMENTASI PEMBELAJARAN ONLINE BERBASIS EDMODO DALAM SITUASI PANDEMIK COVID-19 UNTUK MATERI KEPENDIDIKAN PADA PRODI PENDIDIKAN SENI PERTUNJUKAN
}

\author{
Ujang Nendra Pratama ${ }^{1}$, Galuh Destari Kumala Dewi ${ }^{2}$ \\ Pendidikan Seni Pertunjukan, Institut Seni Indonesia Yogyakarta, \\ Yogyakarta, Indonesia \\ e-mail: ujang.pratama@isi.ac.id ${ }^{1}$, galuhdesta77@gmail.com²

\begin{tabular}{|l|l|l|}
\hline (C) (1) (O) & $\begin{array}{l}\text { This is an open-access article under the } \text { CC BY-SA license. } \\
\text { Copyright } \odot 2020 \text { by Author. Published by Universitas Pendidikan Ganesha. }\end{array}$ \\
\hline Received : November, 2020 & Accepted : November, 2020 & Published : December, 2020 \\
\hline
\end{tabular}

\begin{abstract}
Pandemik COVID-19 telah membawa perubahan besar dan spontan pada ranah pembelajaran, tak terkecuali pada pembelajaran seni pertunjukan di pendidikan tinggi. Pembelajaran tatap muka di kelas diganti menjadi pembelajaran daring. Pengajar perlu untuk mengeksplorasi aplikasi-aplikasi pembelajaran daring guna menyediakan fasilitas belajar di rumah. Tulisan ini menyajikan pembahasan terkait implementasi kelas online berbasis Edmodo sebagai perangkat untuk belajar jarak jauh. Implementasi telah dilakukan pada pengajaran materi pedagogi seni pertunjukan, yaitu Kurikulum dan Pembelajaran, Tata Kelola Pembelajaran, Teknologi Pembelajaran, dan Evaluasi Pembelajaran Seni pada Prodi Pendidikan Seni Pertunjukan. Dari hasil penerapan Edmodo, telah diketahui bahwa sebagian besar mahasiswa mampu lulus berdasarkan nilai akhirnya. Penerapan tersebut merupakan contoh untuk mendiskusikan desain pengajaran online pada subjek pedagogi seni pertunjukan secara lebih lanjut.
\end{abstract}

Kata-kata kunci: Edmodo, pembelajaran online, pembelajaran seni, seni pertunjukan.

\begin{abstract}
The COVID-19 pandemic has brought significant and spontaneous changes to the realm of education, including learning performing arts in higher education. Face-to-face learning in the classroom was replaced by online learning. Teachers need to explore online learning applications to provide learning facilities at home. This paper presents a discussion regarding Edmodo-based online classroom implementation as a tool for distance learning. The implementation has been carried out on performing arts pedagogy courses, namely Curriculum \& Instruction, Classroom Management, Instructional Technology, and Art's Learning Evaluation, in performing art education study programs. From the results of implementing the Edmodo, it is known that most students could pass courses based on their final grades.This implementation is an example of setting online design on the subject of other performing arts pedagogy.
\end{abstract}

Keywords: Edmodo, online learning, art learning, performing art. 


\section{PRASI JURnal Bahasa, SENI, DAN PENGaUARANNYA \\ VOL. 15 | No. 02 | Desember 2020 \\ ISSN: Print 1693-6124 - Online 2614-1116}

Undiksha| DOI: http://dx.doi.org/10.23887/prasi.v15i02.29758 |https://ejournal.undiksha.ac.id/index.php/PRASI

\section{PENDAHULUAN}

Persoalan pembelajaran di Indonesia mengalami urgensi baru pada bulan Maret 2020, pandemik COVID-19 telah menyerang dan memaksa perubahan pada tata kelola pembelajaran dari pendidikan dasar sampai pendidikan tinggi. Pemerintah melalui Surat Edaran Mendikbud No.4/2020 telah mengeluarkan kebijakan terkait pelaksanaan pendidikan dalam masa darurat penyebaran COVID-19 (Kemendikbud, 2020). Semua pengajar dan peserta didik di berbagai tingkat pendidikan mendapatkan dampak dari pembatasan sosial, hal ini mengakibatkan komunitas belajar harus dibatasi, tak terkecuali pada perguruan tinggi bidang seni.

Sekolah dan perguruan tinggi sampai saat ini melaksanakan alternatif pertemuan kelas dengan pembelajaran daring. Segala bentuk sumber belajar berubah menjadi format digital dengan memanfaatkan kelas online. Kelas tersebut dapat berupa grup pada pesan instan (contoh WhatsApp Group), telekonferensi (Zoom, Google Meet, Webex), LMS Moodle, dan jejaring sosial pembelajaran (Google Classroom, Edmodo, Schoology).

Seketika beberapa lembaga pendidikan berupaya untuk mengembangkan eLearning demi menjamin keberlangsungan kegiatan belajar mengajar di institusinya. Beberapa guru dan dosen mulai mengeksplorasi perangkat yang paling mudah untuk dijadikan fasilitas belajar di kelasnya. Namun demikian, bagaimanapun pembelajaran jarak jauh tentu sangat sulit untuk mampu menggantikan pengajaran tatap muka secara esensial, apalagi dalam bidang pembelajaran seni pertunjukan. Pembelajaran pada ranah seni pertunjukan cenderung pada keterampilan praktik. Seperti memperagakan tari (Tari), memainkan alat musik (Musik), dan memerankan tokoh (Drama) membutuhkan kesediaan fasilitas secara fisik dan lingkungan yang memadai.

Keterbatasan fasilitas dan tempat yang dimiliki para mahasiswa mengakibatkan kendala yang jelas. Namun paling tidak untuk mata kuliah terkait teori dan pedagogi seni dapat diantisipasi melalui jejaring sosial pembelajaran. Google Classroom dan Edmodo merupakan perangkat yang dianggap masif dipakai sebagai kelas online (Khanchandani, Chachra, \& Naiksatam, 2019). Sehingga dua aplikasi tersebut umum untuk dimanfaatkan dalam situasi saat ini. Oleh karenanya, bagaimana implementasi perangkat tersebut perlu untuk didiskusikan.

Tulisan ini berfokus pada pembelajaran online dengan jejaring sosial pembelajaran yaitu Edmodo. Edmodo adalah sistem manajemen pembelajaran multi-platform yang sederhana, mudah digunakan, menyediakan fungsi yang berguna bagi pebelajar maupun pengajar untuk berinteraksi secara online di luar kelas. Edmodo dapat diakses melalui web browser dan aplikasi ponsel cerdas (iOS dan Android). Antarmuka pengguna umum untuk semua platform, sederhana dan intuitif mirip seperti Facebook (Charoenwet \& Christensen, 2016:300).

Akademisi yang pernah memanfaatkan Edmodo mengaku bahwa platform ini layak digunakan sepenuhnya untuk tujuan pendidikan, selain itu Edmodo juga tidak berisi komponen atau fitur yang tidak diperlukan bagi pembelajaran (Durak, 2017). Edmodo dapat dinilai dari aspek kolaborasi, kemanfaatan, dukungan instruktur dan kepercayaan diri oleh siswa sebagai pengukuran sikap (Yunkul \& Cankaya, 2017).

Penelitian terdahulu terkait manfaat Edmodo dalam pembelajaran sudah banyak dijumpai, Edmodo dapat meningkatkan kemampuan menulis Bahasa Inggris mahasiswa (Al-Naibi, Al-Jabri, \& Al-Kalbani, 2018). Bahkan, integrasi Edmodo sangat bermanfaat dalam mengembangkan kemampuan menulis hingga tingkat paragraf (Alsmari, 2019). 
Selain itu, mahasiswa menunjukkan respon dan sikap positif terhadap penggunaan Edmodo dalam proses pembelajarannya (Insani, Suherdi, \& Gustine, 2018).

Lebih lanjut dalam bidang pedagogi, Guru SD pra-jabatan cenderung memiliki pandangan positif tentang penggunaan Edmodo dalam program pendidikannya. Sebagian besar menyatakan bahwa Edmodo memberikan kemungkinan untuk berbagi pengetahuan, pengalaman, dan pandangan (Inel-Ekici, 2017). Implementasi Edmodo juga pernah dilakukan pada mata kuliah Pengembangan Kurikulum SD (Rulviana, 2018).

Tulisan ini menyajikan bagaimana implementasi pembelajaran online berbasis Edmodo pada mata kuliah terkait pedagogi seni, yaitu: (1) Kurikulum dan Pembelajaran, (2) Tata Kelola Pembelajaran, (3) Teknologi Pembelajaran, dan (4) Evaluasi Pembelajaran Seni pada Prodi Pendidikan Seni Pertunjukan. Implementasi ini dilakukan pada tiga angkatan kelas mahasiswa Program Studi Pendidikan Seni Pertunjukan ISI Yogyakarta.

\section{METODE PERANCANGAN}

Edmodo dianggap sebagai tool sederhana untuk pembelajaran terpadu yang sesuai proses pembelajaran abad 21, memungkinkan tambahan partisipasi dan dapat membantu pembelajaran dimana dan kapan saja (Wichadee, 2017:151). Edmodo memungkinkan pengembangan tanggung jawab pribadi melalui kegiatan individu dan kolaborasi baik pada kelompok kecil, seluruh kelas, dan pengajar. Pebelajar dapat menjadi lebih disiplin, dan lebih percaya diri dalam menyelesaikan tugasnya sendiri (Khodary, 2017:130).

Terkait perancangan belajar melalui Edmodo, terdapat saran penyajian untuk meningkatkan pengajarannya melalui dua hal (Ryane \& El Faddouli, 2020:69): pertama, perlu memakai aplikasi pesan instan (whatsApp), konten video (Youtube), dan tutorial. Kedua, perlu menambah waktu untuk pekerjaan, menggunakan tabel sintesis untuk menyorot konsep penting dalam materi, serta membuat satu kelas virtual untuk semua kursus.

Meskipun Edmodo memberikan dukungan pada peserta didik untuk mendapatkan akses dan otonomi secara lebih banyak, tapi perlu diperhatikan juga bahwa setiap murid memiliki preferensi sendiri dalam belajar (Mokhtar, 2018: 75). Oleh karenanya, perlu memanfaatkan studi terkait gaya belajar pada subjek terkait. Sebagai contoh adalah hasil analisis gaya belajar berbasis preferensi sensori pada Jurusan Pendidikan Seni Pertunjukan, di mana hasil menyatakan bahwa mayoritas mahasiswa kuat pada modalitas visual (Pratama, 2020).

Pengembangan bahan ajar seperti e-module merupakan salah satu peluang untuk lebih memperkaya penggunaan Edmodo pada pembelajaran (Hidayati, Pangestuti, \& Prayitno, 2019). Modul digital yang memanfaatkan preferensi belajar mahasiswa diharapkan dapat meningkatkan kemudahan memahami materi yang diajarkan.

\section{a. Perancangan Konten Pembelajaran}

Konten pembelajaran yang dibuat perlu lebih ditekankan pada aspek visual, sehingga modul atau presentasi harus berformat infografis. Bahan belajar infografis yang dimaksud adalah memperbanyak simbol-simbol, mengurangi deskripsi verbal yang panjang, dan mendesain pranata lanjutan. Modul pembelajaran dapat dijadikan bahan ajar utama untuk belajar secara mandiri, melalui Edmodo para mahasiswa dapat mengakses dan mengunduh dari ponsel cerdasnya. Pembuatan bahan ajar berbasis infografis dapat 


\section{PRASI JuRnal bahasa, SENI, dAN PEngalarannya \\ VOL. 15 | No. 02 | Desember 2020 \\ ISSN: Print 1693-6124 - Online 2614-1116}

Undiksha| DOI: http://dx.doi.org/10.23887/prasi.v15i02.29758 |https://ejournal.undiksha.ac.id/index.php/PRASI

dikembangkan melalui aplikasi presentasi dengan mengutamakan aspek grafis pada kontennya. Sedangkan untuk distribusinya direkomendasikan dalam format*.pdf agar susunan konten tidak berubah-ubah di berbagai perangkat yang digunakan setiap mahasiswa.

Lebih lanjut, membuat penjelasan dalam bentuk video. Video pembelajaran diperlukan sebagai penjelas dari modul yang diberikan. Keterbatasan waktu dosen terkadang menjadi kendala tersendiri dalam memproduksi serta menjelaskan materi secara lengkap, maka dari itu video dapat berupa pengantar atau pemberian penguatan pada poin-poin utama dalam topik bahan ajar. Video adalah bentuk konten yang tepat mengingat bahwa aspek visual tetap ada, di satu sisi kehadiran dosen dalam video dapat menjadi aspek interaksi emosional tersendiri. Video yang ditampilkan tidak perlu dalam durasi yang terlalu panjang. Cukup 15-30 menit dan distribusinya dapat melalui laman Youtube. Gambar 1 menunjukkan contoh modul digital dan gambar 2 merupakan video dari Youtube.

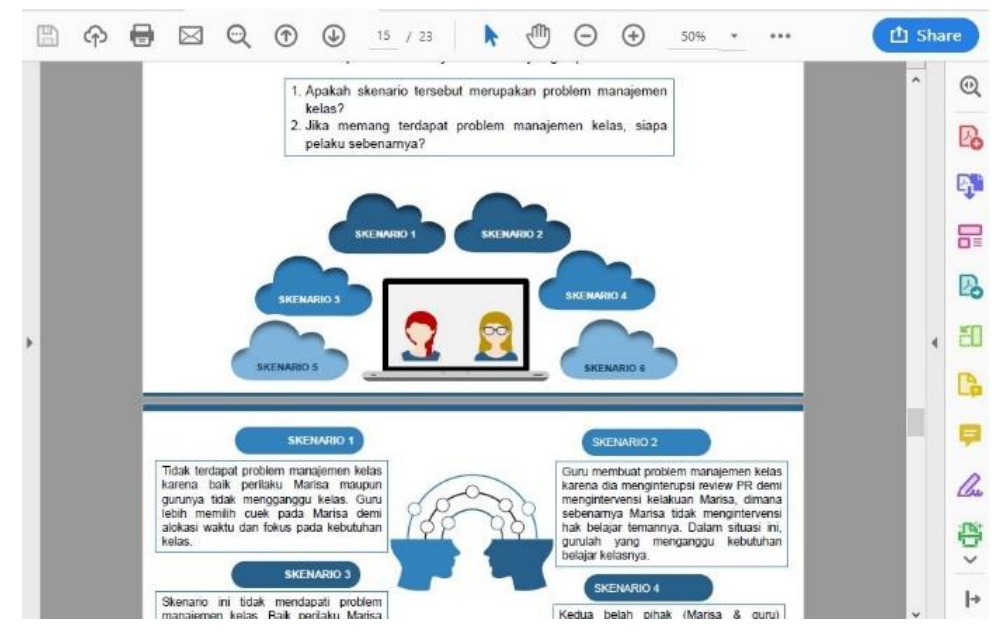

Gambar1. Contoh modul digital

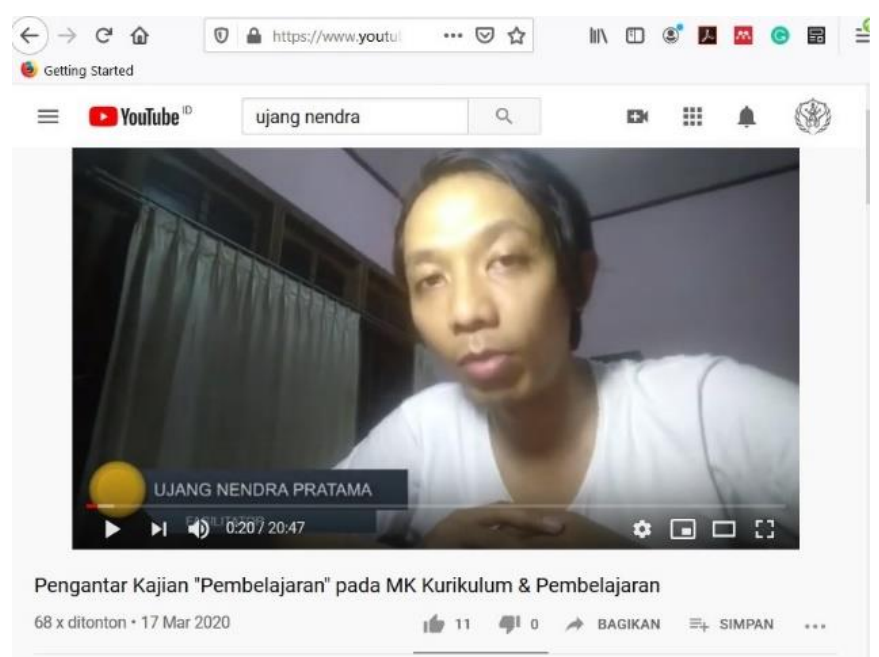

Gambar 2. Contoh video dari Youtube 


\section{b. Perancangan Tugas}

Tugas merupakan bagian yang amat penting dalam pembelajaran secara umum, baik secara tatap muka maupun daring. Tugas dapat dimanfaatkan sebagai alat evaluasi maupun kegiatan belajar mandiri. Dalam aplikasi Edmodo format tugas sangat beragam, dapat berupa penugasan dokumen maupun kuis secara online. Kuis online dapat tersaji dengan pilihan ganda, esai, benar-salah, isian singkat, dan jawaban ganda. Variasi pemberian kuis yang disediakan oleh fitur Edmodo sangat menarik, sehingga diharapkan mahasiswa tidak akan bosan mengikuti kuis-kuis biasa yang hanya monoton.

Tes obyektif dapat disediakan dengan format kuis pilihan ganda, benar-salah, isian singkat. Tes subjektif dapat disediakan dalam bentuk penugasan, pengajar dalam hal ini juga dapat menambahkan template atau dokumen lain yang diperlukan terkait tugas yang diajukan. Seluruh penugasan tersebut nantinya akan terarsip secara digital dan dapat dikoreksi setelah tenggat waktu tugas selesai.

Dalam perkuliahan daring, hendaknya pemberian tugas harus selalu ada. Karena pembelajaran daring sangat berbeda dengan tatap muka. Pada kelas konvensional, dosen dapat melakukan umpan balik dan evaluasi formatif bagi para mahasiswa secara langsung, namun dalam kelas jarak jauh dosen perlu instrumen tambahan terkait hal itu. Selain itu, dalam pembelajaran online secara penuh, hendaknya beban belajar perlu dikurangi, jumlah tugas dipecah menjadi bagian-bagian kecil, dan waktu pengerjaan harus lebih ditolerir. Berdasarkan hasil tugas-tugas yang diberikan tersebut, dosen dapat menjadikannya sebagai pengambilan nilai atau perbaikan pembelajaran lebih lanjut.

Pada mata kuliah Tata Kelola Pembelajaran, Kurikulum \& Pembelajaran, dan Evaluasi Pembelajaran subjek materi bersifat teoritik. Tugas-tugas untuk mata kuliah teori dirancang sesuai dengan tujuan kognitif yang ingin dicapai. Sedangkan dalam mata kuliah Teknologi Pembelajaran, hasil luaran tugas lebih berupa produk-produk baik berupa gambar, video, ataupun file-file digital. Gambar 3 menunjukkan contoh penugasan dengan dokumen template dan Gambar 4 menunjukkan pengarsipan nilai tugas mahasiswa oleh sistem Edmodo.

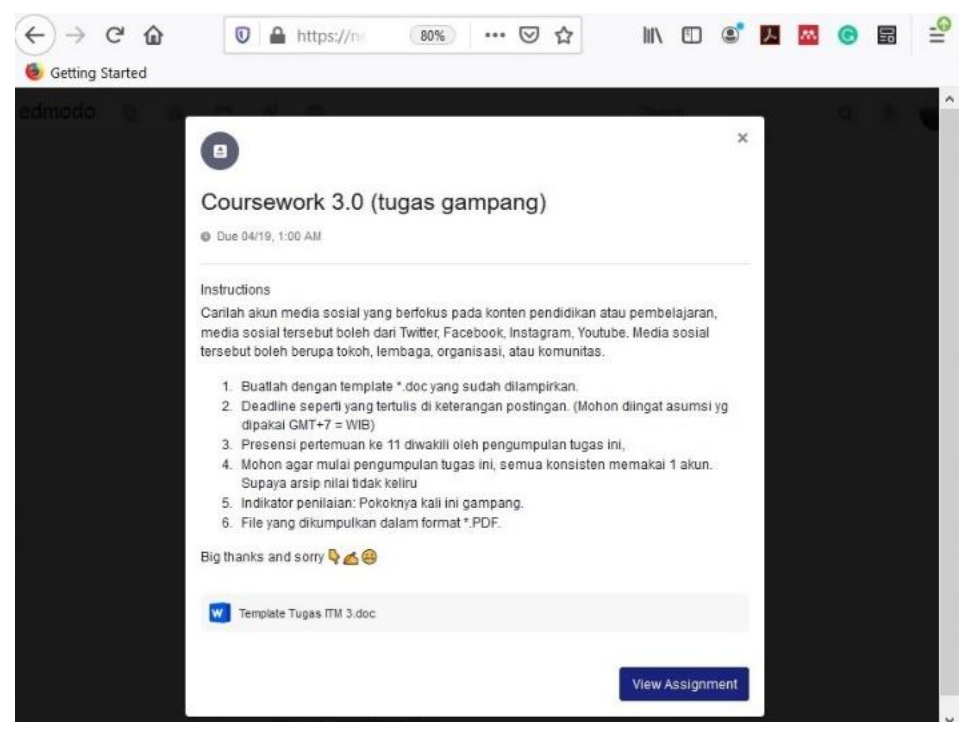

Gambar 3. Contoh penugasan dengan template 


\section{PRASI JURnal Bahasa, SENI, DAN PENGaJARANNYA \\ VOL. 15 | No. 02 | Desember 2020 \\ ISSN: Print 1693-6124 - Online 2614-1116}

Undiksha| DOI: http://dx.doi.org/10.23887/prasi.v15i02.29758 | https://ejournal.undiksha.ac.id/index.php/PRASI

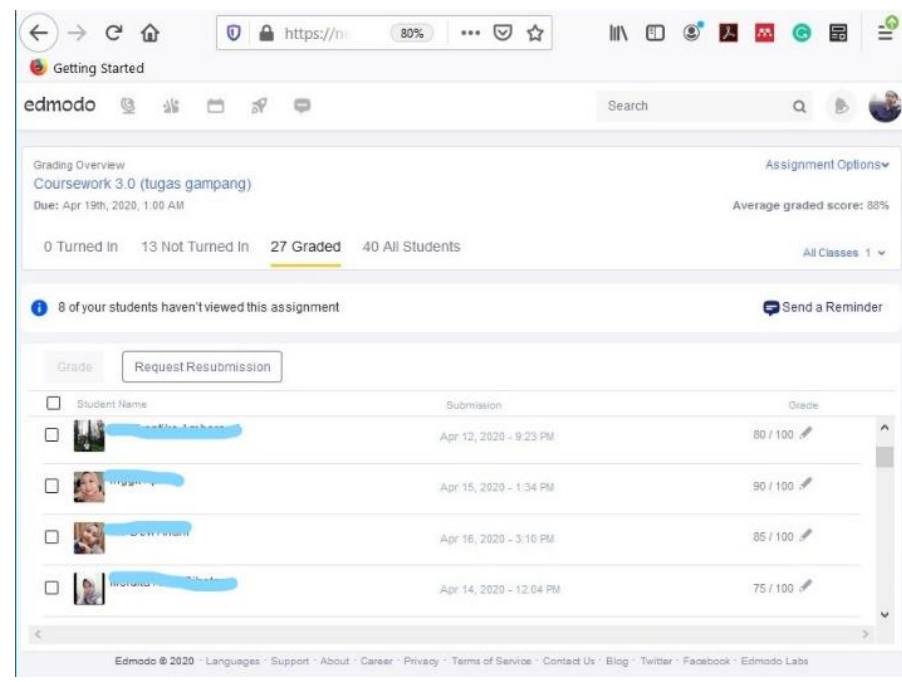

Gambar 4. Contoh arsip nilai penugasan

\section{c. Kegiatan Pembelajaran}

Pelaksanaan pembelajaran menitikberatkan pada konsep belajar tuntas, setiap topiktopik pertemuan harus dikuasai dan ditunjukan dari penugasan atau kuis yang dilalui. Sistem penyampaian daring bersifat asynchronous, artinya komunikasi dosen dan mahasiswa tidak dalam waktu yang sama seperti telepon atau telekonferensi. Skenario belajar diisi dengan model pertemuan kelas, sehingga dalam satu pertemuan berisi: (1) satu topik bahan kuliah (beban disesuaikan); (2) satu penyampaian materi atau tutorial; (3) satu penugasan; dan (4) satu presensi. Meskipun demikian, tidak menutup kemungkinan apabila mahasiswa membutuhkan pengayaan, hal itu dapat diperoleh dari konsultasi melalui pesan online (WhatsApp dan Telegram). Tabel 1 menunjukkan contoh skema implementasi pembelajaran online berbasis Edmodo untuk satu Pertemuan.

Tabel 1. Contoh skema pembelajaran edmodo pada 1 pertemuan

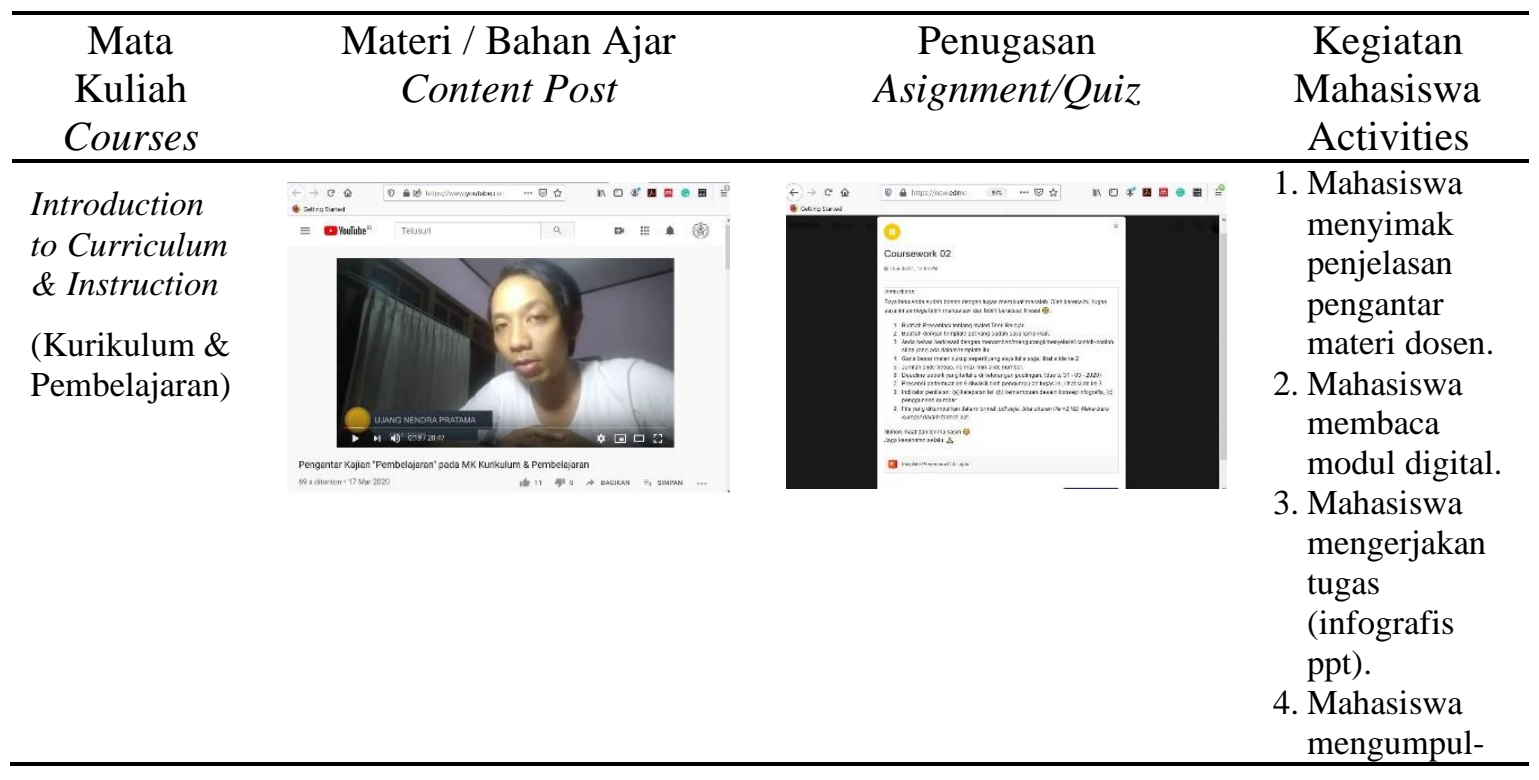




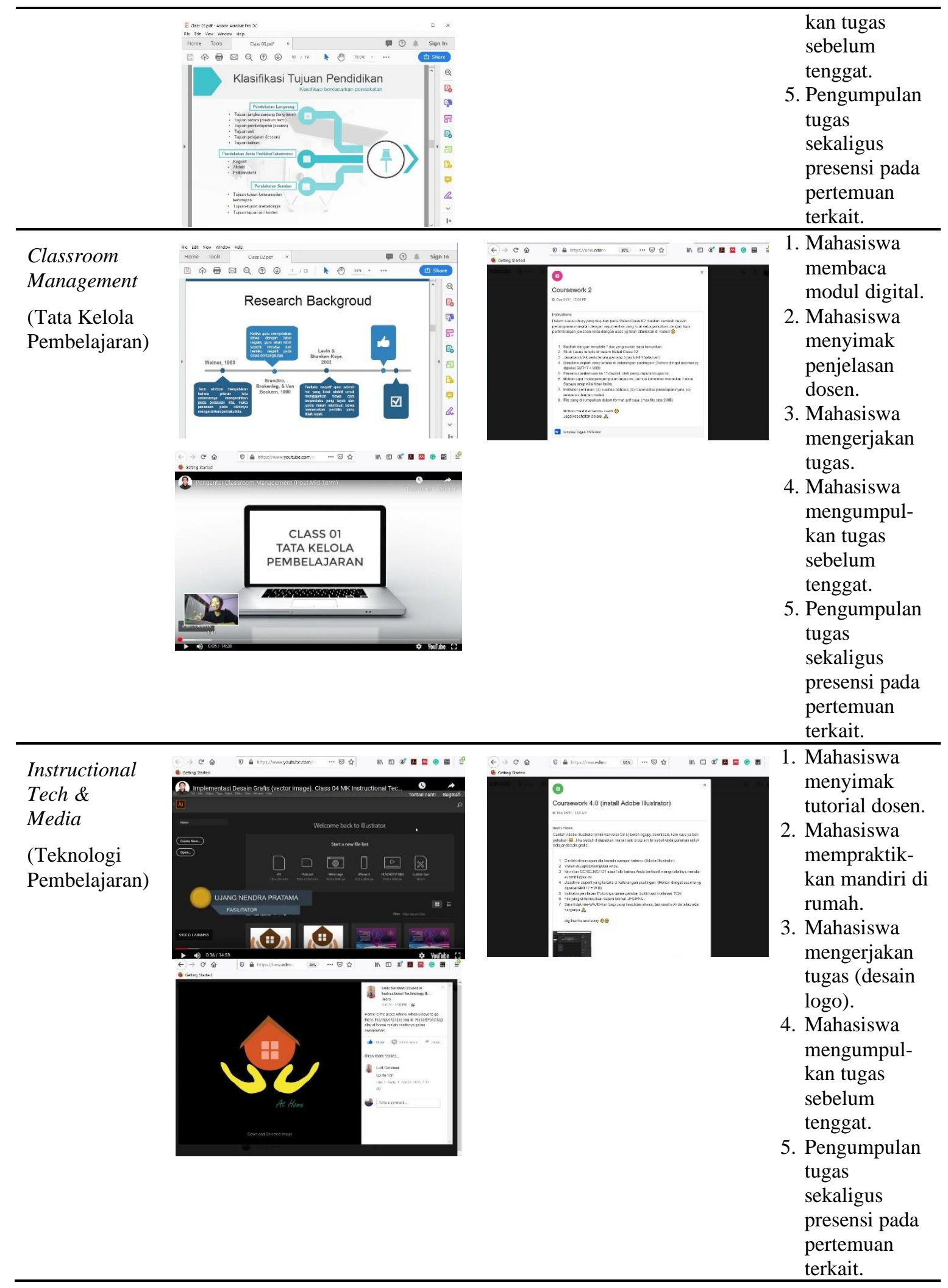




\section{PRASI JuRnal bahasa, SENI, dAN PEngalarannya \\ VOL. 15 | No. 02 | Desember 2020 \\ ISSN: Print 1693-6124 - Online 2614-1116}

Undiksha| DOI: http://dx.doi.org/10.23887/prasi.v15i02.29758 |https://ejournal.undiksha.ac.id/index.php/PRASI

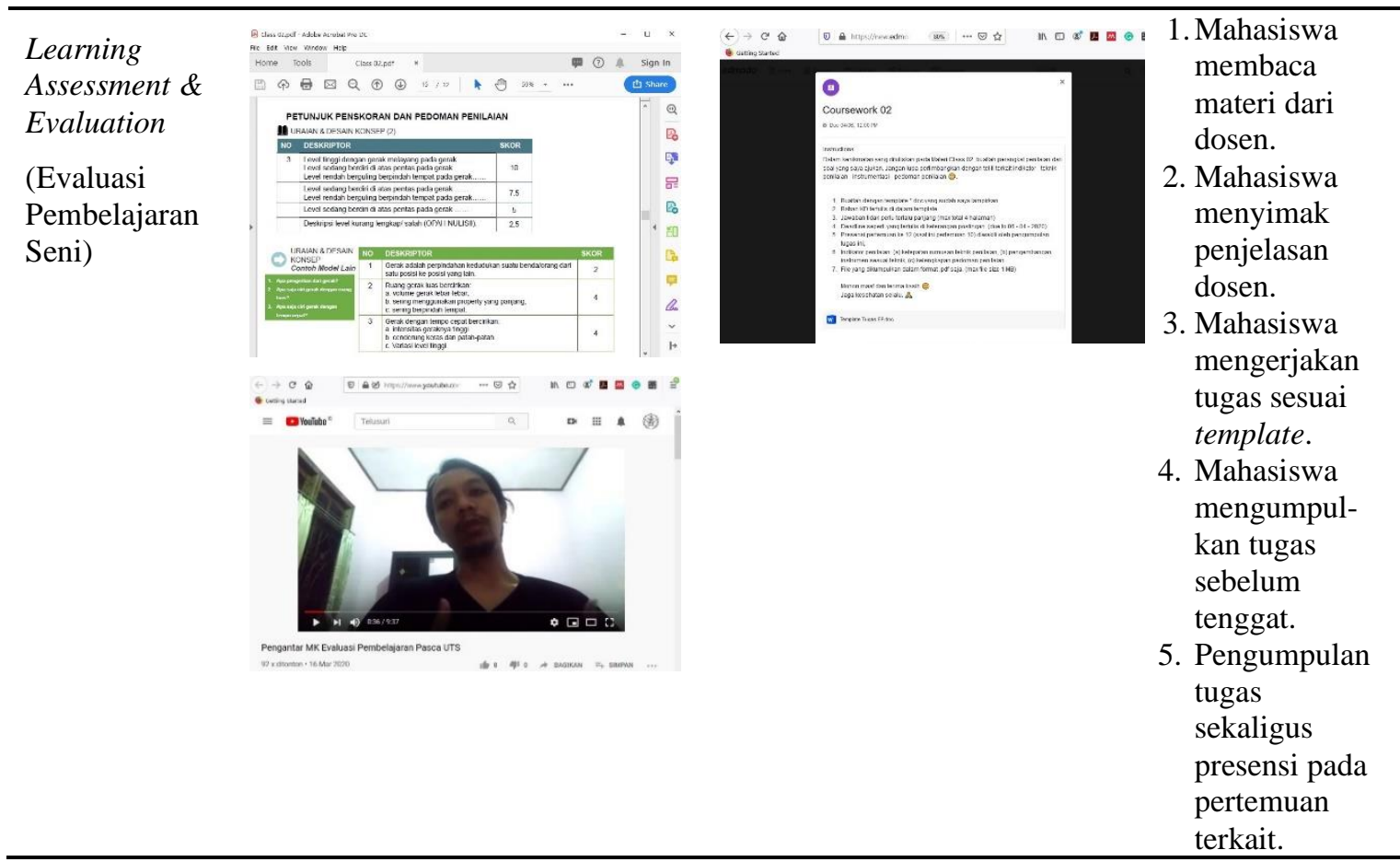

\section{HASIL IMPLEMENTASI EDMODO}

Hasil Implementasi pada Mata Kuliah Kurikulum \& Pembelajaran

Perkuliahan online dilaksanakan dalam 7 pertemuan selama pasca Ujian Tengah Semester (17 Maret - 23 Mei 2020). Dari mata kuliah ini dinyatakan bahwa 93\% mahasiswa telah dinyatakan lulus dan hanya $7 \%$ mahasiswa belum lulus. Berdasarkan implementasi tersebut, dari jumlah total mahasiswa yaitu 44, hanya 3 mahasiswa yang dinyatakan tidak lulus. Selebihnya semua mahasiswa telah memenuhi standar nilai minimal sehingga lulus (41). Rincian kelulusan diperoleh dari distribusi nilai A yang didapatkan oleh 19 mahasiswa, nilai B didapatkan oleh 19 mahasiswa, nilai C didapatkan oleh 3 mahasiswa. Sedangkan untuk 3 mahasiswa yang belum lulus semua memperoleh nilai D. Kelas dari mata kuliah ini merupakan angkatan termuda.

\section{Hasil Implementasi pada Mata Kuliah Tata Kelola Pembelajaran}

Perkuliahan online dilaksanakan dalam 7 pertemuan selama pasca Ujian Tengah Semester (25 Maret - 23 Mei 2020). Dalam mata kuliah Tata Kelola Pembelajaran, sebanyak $91 \%$ mahasiswa dari total seluruhnya telah dinyatakan lulus dan sisanya belum lulus. Berdasarkan implementasi tersebut, jumlah total mahasiswa adalah 46 , sejumlah 42 mahasiswa telah memenuhi syarat untuk lulus dan hanya 4 mahasiswa yang dinyatakan tidak lulus. Rincian kelulusan diperoleh dari distribusi nilai A yang didapatkan oleh 12 mahasiswa, nilai B didapatkan oleh 20 mahasiswa, nilai C didapatkan oleh 10 mahasiswa. Selanjutnya terdapat 4 mahasiswa yang belum lulus karena memperoleh nilai D. Pada mata kuliah ini jumlah mahasiswa merupakan yang paling banyak dibandingkan kelas lainnya.

\section{Hasil Implementasi pada Mata Kuliah Teknologi Pembelajaran}

Mata kuliah Teknologi Pembelajaran merupakan mata kuliah yang memiliki capaian berbeda dari segi luaran kompetensinya. Karena mata kuliah ini terdapat 
penugasan untuk membuat produk. Perkuliahan online dilaksanakan dalam 5 pertemuan dan 2 penugasan proyek selama pasca Ujian Tengah Semester (26 Maret - 22 Mei 2020). Berdasarkan hasil proses belajar yang dilalui, sebanyak 95\% mahasiswa dari kelas tersebut telah dinyatakan lulus dan hanya bersisa $5 \%$ yang belum lulus. Implementasi Edmodo untuk mata kuliah ini diperuntukkan bagi 40 mahasiswa, sejumlah 38 mahasiswa telah mencapai kriteria untuk lulus dan hanya 2 mahasiswa yang belum lulus. Rincian kelulusan diperoleh dari distribusi nilai A yang didapatkan oleh 6 mahasiswa, nilai $\mathrm{B}$ didapatkan oleh 27 mahasiswa, nilai $\mathrm{C}$ didapatkan oleh 5 mahasiswa. Lebih lanjut, terdapat 2 mahasiswa yang belum lulus karena memperoleh nilai E. Mata kuliah ini memiliki angka ketidaklulusan mahasiswa yang terkecil.

\section{Hasil Implementasi pada Mata Kuliah Evaluasi Pembelajaran Seni}

Perkuliahan online dilaksanakan dalam 7 pertemuan selama pasca Ujian Tengah Semester (16 Maret - 23 Mei 2020). Dari pembelajaran tersebut didapatkan hasil bahwa 92\% mahasiswa telah dinyatakan lulus dan $8 \%$ dari mahasiswa belum lulus. Berdasarkan implementasi pada mata kuliah Evaluasi Pembelajaran Seni, dari 39 mahasiswa, sejumlah 36 mahasiswa dinyatakan lulus dan hanya 3 mahasiswa yang tidak lulus. Rincian kelulusan diperoleh dari distribusi nilai A didapatkan oleh 4 mahasiswa, nilai B didapatkan oleh 20 mahasiswa, nilai $\mathrm{C}$ didapatkan oleh 12 mahasiswa. Sedangkan untuk distribusi nilai mahasiswa yang belum lulus diperoleh dari nilai $\mathrm{D}$ dari 2 mahasiswa dan nilai E dari 1 mahasiswa.Rincian nilai hasil pembelajaran dari setiap mata kuliah dapat ditinjau pada Tabel 2.

Tabel 2. Hasil akhir berdasarkan pembelajaran berbasis Edmodo

\begin{tabular}{|c|c|c|c|c|c|c|c|c|c|c|c|}
\hline \multirow[t]{2}{*}{ Mata Kuliah } & \multirow[t]{2}{*}{$\begin{array}{c}\text { Waktu } \\
\text { Pelaksanaan }\end{array}$} & \multirow[t]{2}{*}{$\begin{array}{c}\text { Jumlah } \\
\text { Mahasiswa }\end{array}$} & \multicolumn{5}{|c|}{$\begin{array}{c}\text { Jumlah Mahasiswa } \\
\text { Lulus } \\
\text { Nilai }\end{array}$} & \multicolumn{4}{|c|}{$\begin{array}{c}\text { Jumlah } \\
\text { Mahasiswa } \\
\text { Belum Lulus } \\
\text { Nilai } \\
\end{array}$} \\
\hline & & & $\mathrm{A}$ & $\mathrm{B}$ & $\mathrm{C}$ & $\sum$ & $\%$ & $\mathrm{D}$ & $E$ & $\sum$ & $\%$ \\
\hline $\begin{array}{l}\text { Kurikulum \& } \\
\text { Pembelajaran }\end{array}$ & $\begin{array}{l}17 \text { Maret }-23 \\
\text { Mei } 2020\end{array}$ & 44 & 19 & 19 & 3 & 41 & 93 & 3 & 0 & 3 & 7 \\
\hline $\begin{array}{l}\text { Tata Kelola } \\
\text { Pembelajaran }\end{array}$ & $\begin{array}{l}25 \text { Maret }-23 \\
\text { Mei } 2020\end{array}$ & 46 & 12 & 20 & 10 & 42 & 91 & 4 & 0 & 4 & 9 \\
\hline $\begin{array}{l}\text { Teknologi } \\
\text { Pembelajaran }\end{array}$ & $\begin{array}{l}26 \text { Maret }-22 \\
\text { Mei } 2020\end{array}$ & 40 & 6 & 27 & 5 & 38 & 95 & 0 & 2 & 2 & 5 \\
\hline $\begin{array}{l}\text { Evaluasi } \\
\text { Pembelajaran Seni }\end{array}$ & $\begin{array}{c}16 \text { Maret - } 23 \\
\text { Mei } 2020 \\
\end{array}$ & 39 & 4 & 20 & 12 & 36 & 92 & 2 & 1 & 3 & 8 \\
\hline
\end{tabular}

Pada masing-masing mata kuliah, jumlah mahasiswa yang telah memenuhi nilai minimal untuk lulus menunjukkan di atas 90\%. Oleh karenanya implementasi Edmodo dalam pembelajaran mata kuliah kependidikan (Kurikulum \& Pembelajaran, Tata Kelola Pembelajaran, Teknologi Pembelajaran, Evaluasi Pembelajaran Seni) untuk mahasiswa Pendidikan Seni Pertunjukan dapat dikatakan layak. Hasil ini menunjukkan bahwa implementasi sistem pembelajaran daring yang dipilih oleh pengajar telah mampu memberikan alternatif yang baik di masa pembatasan komunitas belajar tatap muka. 


\section{PRASI JURnal Bahasa, SENI, DAN PENGAJARANNYA \\ VOL. 15 | No. 02 | Desember 2020 \\ ISSN: Print 1693-6124 - Online 2614-1116}

Undiksha | DOI: http://dx.doi.org/10.23887/prasi.v15i02.29758 |https://ejournal.undiksha.ac.id/index.php/PRASI

\section{SIMPULAN}

Berdasarkan perancangan pembelajaran untuk pemanfaatan Edmodo pada mata kuliah pedagogi seni pertunjukan, telah dilakukan beberapa poin penting, yaitu: (1) Perancangan konten pembelajaran menekankan pada format modul digital infografis, agar sesuai dengan gaya belajar visual. Kemudian menambahkan video penjelasan dosen yang terhubung ke laman Youtube; (2) Perancangan tugas menekankan pada unit-unit belajar secara mikro, yaitu untuk bobot 1 pertemuan kelas, tugas-tugas yang diberikan dapat dijadikan cara pengambilan nilai atau perbaikan pembelajaran lebih lanjut; (3) Perancangan kegiatan pembelajaran berfokus pada belajar tuntas dan sistem penyampaian daring bersifat asynchronous.

Berdasarkan implementasi Edmodo pada pembelajaran mata kuliah pedagogi seni pertunjukan, telah didapatkan hasil belajar berupa: (1) Kurikulum \& Pembelajaran, dalam mata kuliah ini 41 mahasiswa telah lulus (93\%); (2) Tata Kelola Pembelajaran, dalam mata kuliah ini 42 mahasiswa (91\%) telah mendapatkan kelulusan; (3) Teknologi Pembelajaran, dalam mata kuliah ini 38 mahasiswa (95\%) dianggap memenuhi kompetensi untuk lulus; terakhir (4) Evaluasi Pembelajaran Seni, pada mata kuliah ini 36 mahasiswa $(92 \%)$ berhasil lulus. Sehingga dapat disimpulkan bahwa mayoritas mahasiswa dapat menjalani proses belajar Edmodo dengan hasil yang baik.

Sebagai langkah ke depan, akan lebih baik apabila dilakukan penelitian terkait persepsi mahasiswa selaku pengguna fasilitas belajar ini. Setelah teknologi pembelajaran di implementasikan, tentu saja hal yang penting untuk diketahui adalah pandangan para pebelajar sendiri terhadap fasilitas yang dipakainya. Penelitian lebih lanjut baik berupa survei pendapat atau eksperimen dengan uji banding produk sejenis merupakan tawaran riset yang layak untuk dilakukan.

\section{DAFTAR PUSTAKA}

Al-Naibi, I., Al-Jabri, M., \& Al-Kalbani, I. 2018. Promoting Students' Paragraph Writing Using Edmodo: An Action Research. TOJET: The Turkish Online Journal of Educational Technology, 17(1), 130-143. Retrieved from https://files.eric.ed.gov/fulltext/EJ1165773.pdf

Alsmari, N. A. 2019. Fostering EFL Students' Paragraph Writing Using Edmodo. English Language Teaching, 12(10), 44-54. https://doi.org/10.5539/elt.v12n10p44

Charoenwet, S., \& Christensen, A. 2016. The Effect of Edmodo Learning Network on Students' Perception, Self-Regulated Learning Behaviors and Learning Performance. Proceedings of The 10th International Multi-Conference on Society, Cybernetics and Informatics 2016, (July), 297-300. Retrieved from http://www.iiis.org/CDs2016/CD2016Summer/papers/EA948HG.pdf

Durak, G. 2017. Using Social Learning Networks (SLNs) in Higher Education: Edmodo Through the Lenses of Academics. International Review of Research in Open and Distributed Learning, 18(1), 84-109. https://doi.org/10.19173/irrodl.v18i1.2623 
Hidayati, N., Pangestuti, A. A., \& Prayitno, T. A. 2019. Edmodo Mobile: Developing eModule on Biology Cell for Online Learning Community. Biosfer: Jurnal Pendidikan Biologi, 12(1), 94-108. https://doi.org/10.21009/biosferjpb.v12n1.94-108

Inel-Ekici, D. 2017. The Use Of Edmodo In Creating An Online Learning Community Of Practice For Learning To Teach Science. Malaysian Online Journal of Educational Sciences, 5(2), 91-106. Retrieved from https://eric.ed.gov/?id=EJ1142512

Insani, H. N., Suherdi, D., \& Gustine, G. G. 2018. Undergraduate Students' Perspectives In Using Edmodo As An Educational Social Network. English Review: Journal of English Education, 6(2), 61-68. https://doi.org/10.25134/erjee.v6i2.1254

Kemendikbud, Republik Indonesia. 2020. Mendikbud Terbitkan SE tentang Pelaksanaan Pendidikan dalam Masa Darurat Covid-19. Retrieved from Kemendikbud RI website: https://www.kemdikbud.go.id/main/blog/2020/03/mendikbud-terbitkanse-tentang-pelaksanaan-pendidikan-dalam-masa-darurat-covid19diakses tanggal 6Mei 2020, pukul 13.00

Khanchandani, K. P., Chachra, S. D., \& Naiksatam, A. 2019. A Comparative Study on Interactive Digital Classrooms: Edmodo and Google. Proceedings - IEEE 10th International Conference on Technology for Education 2019, 205-209. https://doi.org/10.1109/T4E.2019.00046

Khodary, M. M. 2017. Edmodo Use to Develop Saudi EFL Students ' Self-Directed Learning. English Language Teaching, 10(2), 123-135. https://doi.org/10.5539/elt.v10n2p123

Mokhtar, F. A. 2018. Breaking Barriers Through Edmodo: A Qualitative Approach on the Perceptions of University of Malaya Undergraduates. Online Learning, 22(1), 61-80. https://doi.org/10.24059/olj.v22i1.1026

Pratama, U. N. 2020. Analisis Gaya Belajar Mahasiswa Pendidikan Seni Pertunjukan Berdasarkan Modalitas Preferensi Sensori. JINOTEP Jurnal Inovasi Teknologi Pembelajaran, 7(2), 107-115. https://doi.org/10.17977/um031v7i22020p107

Rulviana, V. 2018. Implementasi Media Edmodo dalam Mata Kuliah Pengembangan Kurikulum Sekolah Dasar. Jurnal Refleksi Edukatika, 8(2), 205-208. https://doi.org/10.24176/re.v8i2.2361

Ryane, I., \& El Faddouli, N. 2020. A Case Study of Using Edmodo to Enhance Computer Science Learning for Engineering Students. International Journal of Emerging Technologies in Learning, 15(3), 62-73. https://doi.org/10.3991/ijet.v15i03.11252 
Wichadee, S. 2017. A Development of the Blended Learning Model Using Edmodo for Maximizing Students ' Oral Proficiency and Motivation. International Journal of Emerging Technologies in Learning, 12(2), 137-154. https://doi.org/10.3991/ijet.v12i02.6324

Yunkul, E., \& Cankaya, S. 2017. Students' Attitudes Towards Edmodo, A Social Learning Network: A Scale Development STUDY. Turkish Online Journal of Distance Education, 18(April), 16-29. https://doi.org/10.17718/TOJDE.306554 